\title{
Comparison of Fatty Acid and Biochemical Composition of Cultured Meagre (Argyrosomus regius Asso 1801) in Two Different Regions of Turkey
}

\author{
Seval Dernekbaşı \\ Department of Aquaculture, Faculty of Fisheries, Sinop University, Turkey
}

Copyright $\mathrm{C} 2019$ by authors, all rights reserved. Authors agree that this article remains permanently open access under the terms of the Creative Commons Attribution License 4.0 International License

\begin{abstract}
This study was designed for comparison of biochemical and fatty acid composition of cultured meagre (Argyrosomus regius) in off-shore cage system in two different regions of Turkey. For this purpose, meagre with an average weights of $513.80 \pm 52.40 \mathrm{~g}$ and $726.52 \pm 116.19$ $\mathrm{g}$ were obtained from commercial fish farms in South (Mediterranean) and North (Black Sea) of Turkey, respectively. No significant differences were detected among the fish originated from the Mediterranean (MSO) and the Blacksea (BSO) in terms of body compositions $(p<0.05)$, except crude lipid and moisture $(p>0.05)$. The fatty acid compositions of MSO and BSO fish showed significantly differences ( $\mathrm{p}>0.05)$. The fatty acids such as

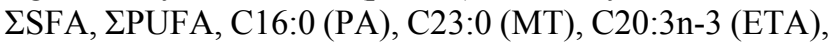
C22:6n-3 (DHA), $\Sigma$ n-3 and n3/n6 were higher in MSO than BSO. Whereas, the fatty acids such as $\Sigma$ MUFA, $\Sigma \mathrm{n}-6$, C18:1n-9 (OLA), C20:1n-9 (EA), C22:1n-9 (ESA), C18:2n-6 (LA) and C18:3n-6 ( $\gamma$-ALA) were higher in BSO fish than MSO fish. However, no difference was detected in the C20:5n-3 (EPA) of fish from both regions. EPA was identified as $3.30 \pm 0.05 \%$ for $\mathrm{MSO}$ and $3.38 \pm 0.05 \%$ for BSO. No differences were detected in the other fatty acids between two regions $(\mathrm{p}<0.05)$. In conclusion, despite the differences in fatty acid compositions of the cultured fish in both regions, high levels of EPA and DHA as well as favorable proportions of n-3 and n- 6 fatty acids showed that meagre was valuable food for human nutrition.
\end{abstract}

Keywords Meagre (Argyrosomus regius), Fatty Acids, Cultured, EPA, DHA

\section{Introduction}

There is evidence suggesting that future fish requirements for human consumption must be covered by increasingly higher ratio with aquaculture and thus a sustainable development of this activity is needed [1] Nowadays, there is a raised interest among aquaculturists around the world for the fast growing species, such as cobia (Rachycentrom canadum), greater amberjack (Seriola dumerili), meagre (Argyrosomus regius), common dolphin fish (Coryphaena hippurus), different species of groupers (Epinephelus sp.) and tuna (Thunnus sp.) [2]. In Turkey, there is a great effort for developing farming techniques for meagre (Argyrosomus regius). In general, fast growing species are carnivorous fish and their culture involves high production cost and high market price. That's why, aquaculture has one of the most modern types of farming application in the World and due to the giant increase in human population, demand for animal products and its derivates is increasing violently, where aquaculture represents one of the most important food supplier to the world [3].

According to FAO data for 2016, the share of aquaculture in total fishing is 46.8. Sea bass (Dicentrarchus labrax) and sea bream (Sparus aurata) are the most preferred fish due to their meat quality, flavoring, and economic value [4]. However, high growth rate [5], good feed conversion, high adaptation capacities and resistance to stress are major aspects that make meagre as a perfect candidate for large-scale fish farming in Europe [6]. The farming of this species is also important for diversifying commercial aquaculture in the Mediterranean and Eastern Atlantic areas. Besides good farming ability, the increasing interest for meagre is imputed to its promising market and quality features, such as interesting form, good processing capacity, high nutritional value, and perfect taste [6].

One of the main quality indexes in farmed fish is the lipid amount and fatty acid (FA) profile stored in the main edible muscles. Some n-3 PUFAs have been regarded as essential for human health (WHO 1977) for their role in preventing and treating a great kind of disorders. Experts in human nutrition and health agree that fish included in the 
daily diet helps prevent certain diseases such as cardiovascular ones. The beneficial effect seems to lie in the lipid component of fish and certain MUFAs and PUFAs, mainly those of the $n-3$ series [1].

Today, the quality parameters of the aquatic products have begun to be discussed together with the changing and developing quality understanding. Especially in fish breeding, meat quality is an important point that cannot be compromised. The most important concepts utilized when revealing meat quality are nutrient and fatty acid composition. In the light of this information, the aim of the present study was the comparison of biochemical and fatty acid composition of cultured meagre in two different regions of Turkey. So, this study was designed for the evaluation of the possible effects of different culture factors on fatty acid contents.

\section{Materials and Methods}

\subsection{Fish Samples}

Meagre with an average weights of $513.80 \pm 52.40 \mathrm{~g}$ and $726.52 \pm 116.19 \mathrm{~g}$ and commercial feed samples were obtained from commercial fish farms in South (Akuvatur Su Ürünleri Company in Adana, Mediterranean) (MSO) and North of Turkey (Kıyak Kardeşler Su Ürünleri Company in Yakakent, Samsun, Black Sea) (BSO), respectively. MSO and BSO fish were fed with commercial feeds, produced in Torbalı Feed Factory (Adana, Turkey) and Sürsan A.S.., (Yakakent/Samsun, Turkey), respectively. The fatty acid compositions of diets were analysed and reported as principal fraction indices in Table 1.Fish were transported to the laboratory in polystyrene boxes with ice. A total of 20 fish from each farm were used for the analyses. All fish were gutted, filleted and minced for analysis. Samples were stored at $-80^{\circ} \mathrm{C}$ until analysis for biochemical and fatty acid compositions.

\subsection{Chemical Analysis}

The chemical composition of fish fillets was determined via proximate composition analysis according to standard methods [7]. Briefly, moisture was determined by drying samples in an oven at $105^{\circ} \mathrm{C}$ to a constant weight. Protein content was determided by measuring nitrogen $(\mathrm{Nx} 6.25)$ using the Kjeldahl method. Lipids were extracted by ether using Soxhlet method, and ash was determined by incinerating samples in a muffle furnace at $550^{\circ} \mathrm{C}$ for $18 \mathrm{~h}$. Gross energy of the diets was estimated assuming $23.6 \mathrm{~kJ} / \mathrm{g}$ protein, $39.5 \mathrm{~kJ} / \mathrm{g}$ lipid and $17 \mathrm{~kJ} / \mathrm{g}$ nitrogen free extracts. All analyses were performed in triplicate.
Table 1. Fatty acid composition of the diets (\% total fatty acids)

\begin{tabular}{|c|c|c|}
\hline Fatty acids & MSO fish diet & BSO fish diet \\
\hline $\mathrm{C} 14: 0$ & 3.98 & 4.71 \\
\hline $\mathrm{C} 16: 0$ & 10.63 & 14.14 \\
\hline $\mathrm{C} 17: 0$ & 0.55 & 0.26 \\
\hline C18:0 & 3.61 & 6.34 \\
\hline C20:0 & 0.45 & 0.32 \\
\hline $\mathrm{C} 22: 0$ & 1.08 & 1.41 \\
\hline C23:0 & 0.11 & 0.11 \\
\hline$\Sigma$ SFA & 24.39 & 27.29 \\
\hline C16:1 & 5.05 & 6.35 \\
\hline $\mathrm{C} 17: 1$ & 0.20 & 0.19 \\
\hline $\mathrm{C} 18: \ln 9$ & 20.50 & 15.28 \\
\hline $\mathrm{C} 18: \ln 9 \mathrm{t}$ & 3.05 & 3.06 \\
\hline C20:1 & 5.21 & 2.12 \\
\hline $\mathrm{C} 20: \ln 9$ & $\mathrm{Nd}$ & $\mathrm{Nd}$ \\
\hline $\mathrm{C} 22: \ln 9$ & 5.51 & 2.17 \\
\hline$\Sigma$ MUFA & 39.52 & 29.17 \\
\hline C18:2n6 & 12.26 & 18.28 \\
\hline C18:3n6 & 6.98 & 5.52 \\
\hline $\mathrm{C} 18: 3 \mathrm{n} 3$ & 1.11 & 1.23 \\
\hline $\mathrm{C} 20: 2$ & 2.40 & 0.25 \\
\hline C20:3n6 & 0.60 & 0.27 \\
\hline $\mathrm{C} 20: 3 \mathrm{n} 3$ & $\mathrm{Nd}$ & $\mathrm{Nd}$ \\
\hline C20:4n6 & 0.86 & 1.41 \\
\hline C20:5n 3 & 6.58 & 8.43 \\
\hline $\mathrm{C} 22: 2$ & 0.10 & 0.10 \\
\hline $\mathrm{C} 22: 6 \mathrm{n} 3$ & 6.34 & 5.28 \\
\hline IPUFA & 37.23 & 41.27 \\
\hline$\Sigma \mathrm{n} 6$ & 20.70 & 25.98 \\
\hline$\Sigma \mathrm{n} 3$ & 14.03 & 14.94 \\
\hline $\mathrm{n} 3 / \mathrm{n} 6$ & 0.68 & 0.58 \\
\hline
\end{tabular}

Nd: not deleted

\subsection{Fatty Acid Analysis}

Total lipid was determined by modified Bligh and Dyer Method [8]. To prepare of fatty acid methyl esters of fish fillets and diets, $0.25 \mathrm{~g}$ of extracted oil was thawed by adding $4 \mathrm{ml}$ of heptane and $0.4 \mathrm{ml}$ of $2 \mathrm{~N} \mathrm{KOH}$ was added. This mixture was stirred in vortex for 2 minutes, and then centrifuged at $5000 \mathrm{rpm}$ for 5 minutes. After centrifugation, $1.5-2 \mathrm{ml}$ of the heptane phase was collected and transferred to glass tubes for GC/MS analysis. The injection of samples into the device was performed with the autosampler AI 1310. 


\subsection{Statistical Analysis}

Samples were analyzed by Thermo Scientific ISQ LT model GC/MS gas chromatography by spectrometer. For this analysis, with $0.25 \mu \mathrm{m}$ film thickness was used a Trace Gold TG-WaxMS capillary column (Thermo Scientific code: $26088-1540$ ) in $0.25 \mu \mathrm{m}$ inner diameter and $60 \mu \mathrm{m}$ length. The injection block temperature was adjusted to $240^{\circ} \mathrm{C}$ and the column temperature program to be increased from $100^{\circ} \mathrm{C}$ to $240^{\circ} \mathrm{C}$. Helium gas $(1 \mathrm{ml} / \mathrm{min})$ was used as a carrier gas and 1:20 split ratio was applied. The MS unit (ISQ LT) was used in electron ionization mode. Fatty acids are defined by comparing the standard FAME mixture of 37 components with respect to their arrival time.

Anderson-Darling and Levene's tests were used for homogeneity of variances and equality of variance of groups, respectively. The significance of differences between biochemical and fatty acid compositions in groups were analyzed using one-way ANOVA, followed by Tukey's method for multiple comparisons. Arcsine square root transformations of percentage data were conducted to achieve homogeneity of variances before statistical analysis. Differences were considered significant when $p<0.05$. Analyses were performed using Statistica 7.0 for Windows.

\section{Results and Discussion}

Meagre (Argyrosomus regius) has great aquaculture potential with growth fast, high of feed conversion rate, living in wide salinity range and quality meat structure. Therefore, it is considered as an alternative species and since 2005, it has been successfully cultivated in off-shore cage systems in the Aegean and Mediterranean. But, the consumer considers many criteria such as the quality, origin and nutritional value of their received product. As a result, the effects of the fish grown on the flavor and quality were started investigating and discussing. So, this study was designed for the evaluation of the possible effects of different culture factors on fatty acid contents.

There were no significant differences between MSO and BSO fish in terms of the crude protein and ash contents $(p>0.05)$ (Table 2). On the other hand, moisture and crude lipid contents were significantly higher in MSO $(p<0.05)$.

Table 2. Proximate composition of cultured meagre (Argyrosomus regius)

\begin{tabular}{ccc}
\hline & MSO & BSO \\
\hline Moisture (\%) & $78.43 \pm 1.96^{\mathrm{a}}$ & $76.47 \pm 1.96^{\mathrm{b}}$ \\
\hline Crude Protein (\%) & $20.97 \pm 0.07^{\mathrm{a}}$ & $20.02 \pm 0.36^{\mathrm{a}}$ \\
\hline Crude Lipid (\%) & $4.61 \pm 0.04^{\mathrm{a}}$ & $3.18 \pm 0.03^{\mathrm{b}}$ \\
\hline Crude Ash (\%) & $2.86 \pm 0.42^{\mathrm{a}}$ & $2.88 \pm 0.52^{\mathrm{a}}$ \\
\hline
\end{tabular}

Different superscripts within the row denote significant differences. MSO: Mediterranian originated fish; BSO: Blacksea originated fish
The main chemical components of fish fillet are water, crude protein, and lipids, which are making up approximately $98 \%$ of the total mass of flesh. The other constituents (i.e., carbohydrates, vitamins, and minerals) are present in minor quantities. The contents of the main components in fish fillets depend primarily on the species, the stage of maturity, sex, spawning cycle, environment, season, and the nutritional condition of the animal [9]. In the present study, there were no differences in crude protein content in fish fillets, but differences in moisture and crude lipid contents were determined. The crude lipid content was $4.61 \pm 0.04$ and $3.18 \pm 0.03 \%$ for MSO and BSO fish, respectively. This case can be explained by that the cultured meagre uses protein in the feed not only for meat efficiency but also for energy metabolism and fat taken from the feed is stored in the body. García Mesa et al. [1]. Reported that lipid content of cultured meagre was higher than wild meagre. Similar results were obtained for species belonging to the same family (brown meagre; Sciaena umbra) by Cakli et al. [10]. As a different fish species, Oz and Dikel [11] reported that body composition of Salmo trutta macrostigma caught from Kokun brook was higher. However, lipid and moisture in the muscle are no found similar to those previously measured in the same species $[12,13,14]$. In the present study, it was determined that BSO fish tended to accumulate less fat.

The fatty acid compositions of the diets (MSO and BSO fish diets) differed in both individual fatty acids and major fatty acid classes (Table 1). Dominant essential fatty acids of fish feeds were myristic acid (MA; C14:0), palmitic acid (PA; C16:0), stearic acid (SA; C18:0) palmitoleic acid (POA; C16:1), oleic acid (OLA; C18:1n-9), linoleic acid (LA; C18:2n-6), $\gamma$-linolenic acid ( $\gamma$-ALA; C18:3n-6), erucic acid (EA; C22:1n-9), eicosapentaenoic acid (EPA; C20:5n-3), and docosahexaenoic acid (DHA; C20:6n-3).

In the present study, the fatty acid profiles in the fillets of fish samples reflected the fatty acid profiles of their diets. However, n-3 PUFA levels in the fillets of MSO fish were indicated significantly higher than BSO fish, although MSO fish diet contain n-3 PUFA less than BSO fish diet. The positive correlation between fatty acid profiles in the diets and fillets of many fish species had also been reported in previous studies $[15,16,12,10,17,18]$. Similar results were obtained by Atalay and Bilal [4] who evaluated different commercial diets in sea bream (Sparus aurata) and sea bass (Dicentrarchus labrax). In addition, Yildiz et al. (2008) studying with the sea bream and sea bass, Grigorakis et al. [18] and Simões et al. [19]studying with meagre reported that the fatty acid composition of fish fillet generally reflects the dietary fatty acids. Most probably, these changes reflect variations in the feeding regime applied during culture. In any case, in the current study, cultured fish in both regions offered good indices of fatty acid quality for human consumption.

The fatty acid compositions of MSO and BSO fish fillets showed significantly differences ( $p>0.05$ ) (Table 3 ). BSO 
fish contained the lowest amount of saturated fatty acids (SFA). Palmitic acid (PA; C16:0) was found to be the highest SFA of fish in both regions. Mono-unsaturated fatty acid (MUFA) was the highest in BSO fish, with oleic acid (OLA; C18:1n-9) constituting the highest content. Also, the MUFAs such as eicosenoic acid (ESA; C20:1n-9), erucic acid (EA; C22:1n-9) in BSO fish were higher than MSO fish. The n-6, linoleic acid (LA; C18:2n-6) and $\gamma-$ Linolenic acid ( $\gamma$-ALA; C18:3n-6) were higher in BSO fish than MSO fish ( $p>0.05$ ). LA is not a normal constituent of marine food chain, which is characterized mostly by polyunsaturated fatty acids [20]. This fatty acid is contained in plant oils included in the feed of cultured fish and is accumulated largely unchanged in the lipids of marine fish because of their reduced capacity for chain elongation and desaturation [10]. In the present study, LA was higher in BSO fish than MSO fish. This may be due to the contain higher amounts of LA of feeds given to cultured fish in black sea.

In the current study, PUFA, n-3, n3/n6 and DHA were the highest in MSO fish ( $>>0.05)$. However, no difference was detected in the EPA of fish from both regions. The EPA was $3.30 \pm 0.05 \%$ for MSO fish and $3.38 \pm 0.05 \%$ for BSO fish. No differences were detected between the other fatty acids of fish in both regions $(\mathrm{p}<0.05)$. Cultured meagre contained significantly higher levels of n-3 PUFA than wild forms of this fish. Yet, consumption of both wild and cultured meagre will contribute to dietary $n-3$ PUFA intake with benefits to human health. This may be the result of changes in diet and the intake of lipid.

The fatty acid profiles of some wild and cultured fish species were comparised with the results of present study in Table 4. Cakli et al. [10] reported that cultured brown meagre in Aegean had significantly higher values of MUFA, while wild specimen contained higher levels of saturates. The reason for these differences, higher levels of monoenes and n-9 resulted from the increased presence of 18:1n-9 in tissues of cultured brown meagre, while 16:0 and 18:0 were contributing to the higher levels of saturates in wild brown meagre. These type of differences have also been observed for a number of other species like Atlantic salmon [21], red sea bream [22], red porgy [23], turbot [24] and rainbow trout (Oncorhynchus mykiss) [25]. In general, the fatty acid profiles of cultured and wild fish are similar. Even, in terms of n3 PUFA, cultured fish has a richer fatty acid than wild ones. Probably, this may have been due to the content of the feed used for feeding the fish. However, production of cultured fish with fatty acid profiles similar to those of wild ones might aid in the production of fish of similar taste characteristics. According to the results of the current study, PUFA had significantly higher than MUFA.

Table 3. Fatty acid composition of the cultured meagre, Argyrosomus regius (\% total fatty acids)

\begin{tabular}{|c|c|c|}
\hline Fatty acids & MSO fish & BSO fish \\
\hline $\mathrm{C} 14: 0$ & $1.42 \pm 0.06^{\mathrm{a}}$ & $1.37 \pm 0.16^{\mathrm{a}}$ \\
\hline C16:0 & $18.57 \pm 0.01^{\mathrm{a}}$ & $16.69 \pm 0.19^{b}$ \\
\hline C17:0 & $0.40 \pm 0.05^{\mathrm{a}}$ & $0.18 \pm 0.00^{b}$ \\
\hline C18:0 & $11.46 \pm 0.40^{\mathrm{a}}$ & $12.01 \pm 1.32^{\mathrm{a}}$ \\
\hline $\mathrm{C} 20: 0$ & $0.05^{\mathrm{a}}$ & $0.06^{\mathrm{a}}$ \\
\hline $\mathrm{C} 22: 0$ & $0.07 \pm 0.01^{\mathrm{a}}$ & $0.06 \pm 0.02^{\mathrm{a}}$ \\
\hline $\mathrm{C} 23: 0$ & $1.44 \pm 0.04^{\mathrm{a}}$ & $0.60 \pm 0.13^{b}$ \\
\hline ¿SFA & $33.35 \pm 0.43^{\mathrm{a}}$ & $30.89 \pm 0.28^{b}$ \\
\hline C16:1 & $2.24 \pm 0.12^{\mathrm{a}}$ & $2.24 \pm 0.25^{\mathrm{a}}$ \\
\hline $\mathrm{C} 17: 1$ & $0.31 \pm 0.05^{\mathrm{a}}$ & $0.20 \pm 0.01^{\mathrm{a}}$ \\
\hline C18:1n9 & $14.66 \pm 1.00^{\mathrm{a}}$ & $17.82 \pm 0.01^{\mathrm{b}}$ \\
\hline $\mathrm{C} 20: \ln 9$ & $1.46 \pm 0.07^{\mathrm{a}}$ & $1.76 \pm 0.18^{b}$ \\
\hline $\mathrm{C} 22: \ln 9$ & $0.58 \pm 0.07^{\mathrm{a}}$ & $0.98 \pm 0.16^{\mathrm{b}}$ \\
\hline IMUFA & $19.23 \pm 1.19^{\mathrm{a}}$ & $23.00 \pm 0.60^{b}$ \\
\hline C18:2n6 & $14.08 \pm 0.16^{\mathrm{a}}$ & $20.34 \pm 0.25^{b}$ \\
\hline C18:3n6 & $1.36 \pm 0.04^{\mathrm{a}}$ & $2.25 \pm 0.20^{\mathrm{b}}$ \\
\hline C18:3n3 & $0.24 \pm 0.01^{\mathrm{a}}$ & $0.28 \pm 0.04^{\mathrm{a}}$ \\
\hline $\mathrm{C} 20: 2$ & $0.51 \pm 0.02^{\mathrm{a}}$ & $0.52 \pm 0.00^{\mathrm{a}}$ \\
\hline $\mathrm{C} 20: 3 \mathrm{n} 6$ & $0.25 \pm 0.03^{\mathrm{a}}$ & $0.17 \pm 0.02^{\mathrm{a}}$ \\
\hline $\mathrm{C} 20: 3 \mathrm{n} 3$ & $1.81 \pm 0.06^{\mathrm{a}}$ & $1.20 \pm 0.20^{\mathrm{b}}$ \\
\hline $\mathrm{C} 20: 4 \mathrm{n} 6$ & $0.10 \pm 0.02^{\mathrm{a}}$ & $0.18 \pm 0.03^{\mathrm{a}}$ \\
\hline $\mathrm{C} 20: 5 \mathrm{n} 3$ & $3.30 \pm 0.05^{\mathrm{a}}$ & $3.38 \pm 0.05^{\mathrm{a}}$ \\
\hline $\mathrm{C} 22: 2$ & $0.14 \pm 0.06^{\mathrm{a}}$ & $0.10 \pm 0.06^{\mathrm{a}}$ \\
\hline $\mathrm{C} 22: 6 \mathrm{n} 3$ & $25.92 \pm 0.79^{\mathrm{a}}$ & $17.66 \pm 2.43^{b}$ \\
\hline 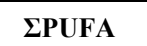 & $47.70 \pm 0.65^{a}$ & $46.07 \pm 0.39^{b}$ \\
\hline$\Sigma \mathrm{n} 6$ & $15.78 \pm 0.19^{\mathrm{a}}$ & $22.93 \pm 0.14^{\mathrm{b}}$ \\
\hline$\Sigma \mathrm{n} 3$ & $31.27 \pm 0.83^{\mathrm{a}}$ & $22.52 \pm 0.52^{b}$ \\
\hline $\mathrm{n} 3 / \mathrm{n} 6$ & $1.98 \pm 0.08^{\mathrm{a}}$ & $0.98 \pm 0.03^{b}$ \\
\hline
\end{tabular}

Different superscripts within the row denote significant differences.

SFA: Saturated fatty acids, MUFA: Monounsaturated fatty acids, PUFA: Polyunsaturated fatty acids,

MSO: Mediterranian originated fish; BSO: Blacksea originated fish 
Table 4. Comparison of the fatty acid profiles of some wild and cultured fish species

\begin{tabular}{|c|c|c|c|c|c|c|c|c|c|c|c|}
\hline \multirow{3}{*}{$\begin{array}{l}\text { Fatty } \\
\text { Acids }\end{array}$} & \multicolumn{3}{|c|}{ Mediterranean } & \multirow{2}{*}{\multicolumn{2}{|c|}{$\begin{array}{c}\begin{array}{c}\text { Northwest } \\
\text { Greece }^{\mathbf{2 6}}\end{array} \\
\text { Sea bream } \\
\text { (Wild) (Cultured) }\end{array}$}} & \multicolumn{2}{|c|}{ Aegean $^{16}$} & \multirow{3}{*}{$\begin{array}{c}\text { Black Sea } \\
\begin{array}{c}\text { Meagre } \\
\text { (Cultured) }\end{array} \\
3.38 \\
\end{array}$} & \multirow{3}{*}{$\begin{array}{c}\text { Spain }^{1} \\
\begin{array}{c}\text { Meagre } \\
\text { (Cultured) }\end{array} \\
3.59 \\
\end{array}$} & \multirow{2}{*}{\multicolumn{2}{|c|}{$\begin{array}{c}\text { Aegean }^{\mathbf{1 0}} \\
\text { Brown Meagre } \\
\text { (Wild) } \\
\text { (Cultured) } \\
\end{array}$}} \\
\hline & $\begin{array}{l}\text { Meagre* } \\
\text { (Culturd) }\end{array}$ & \multicolumn{2}{|c|}{$\begin{array}{l}\text { Sea bass }^{21} \\
\text { (Wild) } \\
\text { (Cultured) }\end{array}$} & & & \multirow{2}{*}{$\begin{array}{c}\begin{array}{c}\text { Sea } \\
\text { bass } \\
\text { (Wild) }\end{array} \\
5.0\end{array}$} & \multirow{2}{*}{$\begin{array}{c}\begin{array}{c}\text { Sea } \\
\text { bream } \\
\text { (Wild) }\end{array} \\
5.0\end{array}$} & & & & \\
\hline & 3.30 & 6.77 & 5.53 & 0.28 & 4.49 & & & & & - & - \\
\hline DHA & 25.92 & 14.01 & 9.42 & 9.54 & 9.19 & 11.4 & 11.1 & 17.66 & 14.05 & - & - \\
\hline$n-3$ & 31.27 & 22.49 & 15.98 & 15.87 & 19.89 & 18.3 & 17.6 & 22.52 & 20.64 & 9.84 & 9.21 \\
\hline$n-6$ & 15.78 & 11.13 & 15.59 & 7.21 & 12.20 & 14.2 & 10.6 & 22.93 & 19.96 & 2.77 & 8.29 \\
\hline SFA & 33.35 & 26.49 & 25.10 & 27.36 & 20.18 & 24.5 & 27.1 & 30.89 & 23.92 & 50.47 & 41.89 \\
\hline MUFA & 19.23 & 27.55 & 30.14 & 37.67 & 39.47 & 28.1 & 29.8 & 23.0 & 29.48 & 30.15 & 41.14 \\
\hline PUFA & 47.70 & 30.06 & 35.06 & 23.08 & 32.09 & 32.5 & 28.2 & 46.07 & 40.54 & 19.38 & 16.98 \\
\hline
\end{tabular}

*Results in the present study.

\section{Conclusions}

Fish is an important source of nutritious n-3 fatty acids, which are necessary for the prevention of cardiovascular and neurological diseases [28]. In this study, biochemical and fatty acid compounds of meagre cultured in two different regions of Turkey were compared and the possible effects of different culture media were evaluated. In conclusion, despite the differences in fatty acid compositions of the cultured fish in both regions, high levels of EPA and DHA as well as favorable proportions

\section{Acknowledgements}

We thank Akuvatur Su Ürünleri Company in Adana (Mediterranean) and Kıyak Kardeşler Su Ürünleri Company in Samsun (Black Sea) for providing the experimental fish.

\section{REFERENCES}

[1] García Mesa, S., Suárez, M.D., Rincón Cervera, M.A., Guil Guerrero, J.L., González, G., Cárdenas, S. and García Gallego, M. 2014. Time course of muscle fatty acid composition of cultured meagre (Argyrosomus regius) during the first sixteen months of a cage culture. Grasas Y Aceites 65(1): 1-9. DOI: http://dx.doi.org/10.3989/gya.0498 13

[2] Anastasiades, G. 2010. Biodiversity in eastern Mediterranean marine aquaculture: an approach to new species. Ph.D. Thesis, University of Insubria, Department of Biotechnology and Molecular Sciences, Varese, Italy.

[3] Fernandes, J.P.L.C. 2013. Optimizing the dietary protein:lipid ratio on meagre (Argyrosomus regius): effects on growth and lipid deposition. Universidade de Lisboa, Faculdade de Ciências, Departamento de Biologia Animal, 55 p. Portugal.

[4] Atalay, H. and Bilal, T. 2014. The effect of using different commercial feeds in sea bream (Sparus aurata L. 1758) and sea bass (Dicentrarchus labrax L. 1758) aquacultured in the Güllük Gulf (Muğla, Türkiye) on fatty acid profile. Turkish Journal of Veterinary and Animal Sciences 38: 20-25. DOI:10.3906/vet-1304-3

[5] Quéméner, L., Suquet, M., Mero, D. and Gaignon, J.L. 2002. Selection method of new candidates for finfish aquaculture: the cas[e of the French Atlantic, the Channel and the North Sea coasts. Aquat. Living Resour 15: 293-302.

[6] Monfort, M.C. 2010. Present market situation and prospects of meagre (Argyrosomus regius), as an emerging species in Mediterranean aquaculture. Studies and Reviews. General Fisheries Commission for the Mediterranean. No. 89. Rome, FAO. 28p.

[7] AOAC. 1995. Official Methods of Analysis. 16th ed. Association of Official Analytical Chemists, Arlington, VA.

[8] Hanson, S.W.F. and Olley, J. 1963. Application of the Bligh and Dyer method of lipid extraction to tissue homogenates. Biochemical Journal 89: 101-102.

[9] Kocatepe, D. and Turan, H. 2012.Proximate and fatty acid composition of some commercially important fish species from the Sinop Region of the Black Sea. Lipids 47: 635-641. DOI: $10.1007 / \mathrm{s} 11745-012-3658-1$

[10] Cakli, Ş., Dincer, T., Cadun, A., Saka, Ş. and Firat, A. 2006. Nutriment content comparison of the new culture species Brown meagre (Sciaena umbra). Archiv für Lebensmittelhygiene 57: 80-84.

[11] Oz, M. and Dikel, S. 2015. Body compositions and fatty acid profile of Salmo trutta macrostigma caught from Korkun brook. Advances in Zoology and Botany 3(4):190-192. DOI: 10.13189/azb.2015.030405.

[12] Poli, B.M., Parisi, G. and Zampacavallo, G. 2003. Preliminary results on quality and quality changes in reared meagre (Argyrosomus regius): body and fillet traits and freshness changes in refrigerated commercial-size fish. Aquaculture International 11: 301-311.

[13] Segato, S., Corato, A., Fasolato, L. and Andrighetto, I. 2005. Effect of the partial replacement of fish meal and oil by vegetable products on performance and quality traits of juvenile shi drum (Umbrina cirrosa L.)., Italian Journal of Animal Science 4:159-166. 
[14] Hernández, M.D., López, M.B., Álvarez, A., Ferrandini, E., García, B. and Garrido, M.D. 2009. Sensory, physical, chemical and microbiological changes in aquacultured meagre (Argyrosomus regius) fillets during ice storage. Food Chemistry 114, 237-245.

[15] Alasavar, C., Taylor, K.D.A., Zubcov, E., Shahidi, F. and Alexis, M. 2002.Differentation of cultured and wild sea bass (Dicentrarchus labrax): total lipid content, fatty acid and trace mineral composition. Food Chemistry 79: 145-150. DOI:10.1016/j.foodchem.2008.09.045.

[16] Cordier, M., Brichon, G., Weber, J.-M. and Zwingelstein, G. 2002. Changes in the fatty acid composition of phospholipids in tissues of farmed sea bass (Dicentrarchus labrax) during an annual cycle:role of environmental temperature and salinity. Comp. Biochem. Physiol. B. 133:281-288.

[17] Yildiz, M., Sener, E. and Timur, M. 2008. Effects of differences in diet and seasonal changes on the fatty acid composition in fillets from farmed and wild sea bream (Sparus aurata L.) and sea bass (Dicentrarchus labrax L.). International Journal of Food Science and Technology 43: 853-858. DOI:10.1111/j.1365-2621.2007.01526.x.

[18] Grikorakis, K., Fountoulaki, E., Vasilaki, A., Mittakos, I. and Nathanailides, C. 2011. Lipid quality and filleting yield of reared meagre (Argyrosomus regius). International Journal of Food Science and Technology 46: 711-716. DOI:10.1111/j.1365-2621.2010.02537.x

[19] Simões, T., Fonseca, S.B., Augusto, A., Granada, L., Ozório, R.O.A., Gonçalves, J.F.M., Pascoal, L.A.F., Silva, J.H.V. and Lemos, M.F.L. 2017: Changes in fatty acid profile and chemical composition of meagre (Argyrosomus regius) fed with different lipid and selenium levels. Eur. J. Lipid Sci. Technol. 119: 1-12. DOI: 10.1002/ejlt.201600016.

[20] Sargent, J., Bell, G., McEvoy, L., Tocher, D. and Estevez, A. 1999. Recent developments in the essential fatty acid nutrition of fish. Aquaculture 177:191-199.

[21] Bergstrom, E. 1989. Effect of natural and artificial diets on seasonal changes in fatty acid composition and total body lipid content of wild and hatchery reared Atlantic salmon (Salmo salar L.) parr-smolt. Aquaculture 82: 205-217.

[22] Morishita, T., Uno, K., Araki, T. And Takahashi, T. 1989. Comparison of the fatty acid compositions in cultured red sea bream differing in the localities and culture methods and those in the wild fish. Nippon Suisan Gakkai Shi 55:847852.

[23] Rueda, F.M., López, J.A., Martínez, F.J., Zamora, S., Divanach, P. and Kentouri, M. 1997. Fatty acids in muscle of wild and farmed red porgy, Pagrus pagrus. Aquaculture Nutrition 3:161-165.

[24] Serot, T., Gandemer, G. and Demaimay, M. 1998. Lipid and fatty acid compositions of muscle from farmed and wild adult turbot. Aquac. Int. 6: 331-343.

[25] Oz, M. and Dikel, S. 2015. Comparison of body compositions and fatty acid profiles of farmed and wild rainbow trout (Oncorhynchus mykiss). Food Science and Technology 3(4): 56-60. DOI: 10.13189/fst.2015.030402.

[26] Lenas, D.S., Triantafillou, D.J., Chatziantoniou, S. and Nathanailides, C. 2011. Fatty acid profile of wild and farmed gilthead sea bream (Sparus aurata). J. Verbr. Lebensm. 6 : 435-440. DoI: 10.1007/s00003-011-0695-2.

[27] Baki, B., Gönener, S. and Kaya, D. 2015. Comparison of Food, Amino Acid and Fatty Acid Compositions of Wild and Cultivated Sea Bass (Dicentrarchus labrax L., 1758). Turkish Journal of Fisheries and Aquatic Sciences 15: 175-179.

[28] Murillo, E., Rao, K.S. and Durant, A.A. 2014.The lipid content and fatty acid composition of four eastern central Pacific native fish species. Journal of Food Composition and Analysis 33: 1-5. DOI: http://dx.doi.org/10.1016/j.jfca.201 3.08.007 